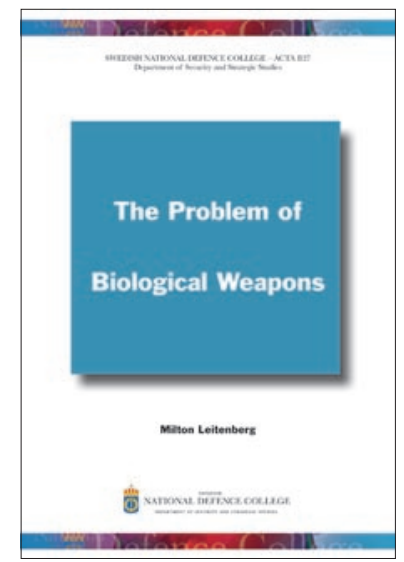

\title{
The problem of biological weapons
}

\author{
Milton Leitenberg \\ The Swedish National Defence College. Stockholm, Sweden. 2004. \\ 206 pp. \$27.00. ISBN: 9-189-68327-7 (softcover).
}

Reviewed by Leonard A. Cole

Rutgers University, Newark, New Jersey, USA.

E-mail: Icole1@ix.netcom.com

W

hen letters containing anthrax spores were mailed within the United States in the fall of 2001, concerns about bioterrrorism mushroomed. Funding for bioterrorismrelated research by the NIH climbed from $\$ 340$ million in 2002 to nearly \$1.7 billion in each of the next two years. Anxiety was fueled in part by intelligence reports that Al Qaeda, the group behind the September 11 attack, had also sought biological weapons capabilities.

The deliberate dissemination of anthrax bacteria capped a decade of unsettling incidents concerning biological weapons. In 1992, Russian President Boris Yeltsin acknowledged that the former Soviet Union had developed tons of anthrax, plague, and other forbidden warfare agents. A few years later, pressed by United Nations weapons inspectors, Iraqi officials admitted to an illegal biological arsenal far more extensive than previously acknowledged. In each case, Western analysts were surprised by the magnitude of the subterfuge.

The discoveries about the state programs came amid troubling findings about nonstate actors as well, most notably the Aum Shinrikyo group. This Japanese cult released the chemical sarin in the Tokyo subway in 1995 and on other occasions unleashed anthrax spores. The sarin caused death and injury, but the anthrax turned out to be from a nonlethal strain that harmed no one. Still, the threat of germ weapons gained increasing attention. Media reports and warnings by public officials suggested that the United States was unprepared for a bioattack.

In assessing these and other issues in The problem of biological weapons, Milton Leitenberg mounts a multi-front critique on US policy. He maintains that government officials and the media have exaggerated the threat of bioweapons, especially by nonstate actors. These exaggerations, he believes, probably had the unintended effect of stimulating interest in biological weapons by Al Qaeda and other terrorist groups. He also disparages the large expansion of biodefense research and development for two reasons. First, the amount of money now going toward this research is disproportionately large compared with that being spent in other public health areas. Second, the expanded research programs are likely to increase what Leitenberg terms "the wrong kind of interest" in biological weapons and, in consequence, promote their proliferation.

Whether or not the threat of bioweapons and bioterrorism has been exaggerated is largely a matter of perception. True, until now, pathogenic organisms have rarely been used as weapons of war. Japan's release of plague bacteria over China in the 1930s and 1940s was a singular exception. Incidents of bioterrorism are also rare. In fact, the only recorded deaths from bioterrorism in the US resulted from the anthrax attacks in 2001. Biological weapons have been used infrequently due to difficulty in obtaining and processing the pathogens, uncertainty that they will affect an intended target, and, in some cases, moral inhibitions.

For Leitenberg, the infrequency of use arises largely from the technical challenges in producing an effective bioweapon. If not for this, he contends, efforts to mount bioattacks by the Aum Shinrikyo cult and other nonstate actors would have been successful. There is some merit to this presumption. But the technical complexity argument was surely weakened when in 1984 members of the Rajneesh cult released salmonella bacteria in Oregon restaurants. More than 750 people became ill, though none died. The seed bacteria were obtained from a commercial supplier, grown and processed under the supervision of a nurse, and dispensed when cult members poured a liquid mixture containing salmonella on food in salad bars. With similar simplicity, a more virulent strain of bacteria might be unleashed with devastating effects.

For much of the nation, the anthrax attacks in 2001 was a frightening event. Perhaps a half-dozen letters were mailed, each containing about a gram of spores. Anthrax spores evidently had leaked from the envelopes and left a trail of contamination. Anthrax-infected government buildings, postal facilities, and news offices were shut down, and people everywhere were afraid to open mail. Twentytwo people became ill; five of them died.

Leitenberg claims that the public believed, inappropriately, that bioterrorism had become the most urgent public health problem because of "massive and frequently misleading media attention" about the anthrax attacks. But this view was based on a survey taken on November 8, 2001, one week after a New York woman died of inhalation anthrax despite no known contact with the bacterium. The New York Times said her death suggested a "widening threat," and The Washington Post said it might "signal a new front" in the anthrax attacks. Such expressions in the media were proper because no one knew how she became infected or when the outbreak would end. The end did not come until November 21, with the death of a Connecticut woman.

During the outbreak, 30,000 people at risk of exposure received prophylactic antibiotics, which doubtless saved many from infection. If the anthrax strain had been drug resistant, and if hundreds of anthrax letters had been mailed, the toll could have been far greater. In this respect, the anthrax attacks demonstrated a frightening potential. On this matter and others, Leitenberg's book, while uneven, offers provocative assessments about an important subject. 